\title{
Hyperloop Academic Research: A Systematic Review and a Taxonomy of Issues
}

\author{
Konstantinos Gkoumas
}

check for

updates

Citation: Gkoumas, K. Hyperloop Academic Research: A Systematic Review and a Taxonomy of Issues. Appl. Sci. 2021, 11, 5951. https:// doi.org/10.3390/app11135951

Academic Editor: Nicola Bosso

Received: 24 May 2021

Accepted: 24 June 2021

Published: 26 June 2021

Publisher's Note: MDPI stays neutral with regard to jurisdictional claims in published maps and institutional affiliations.

Copyright: (C) 2021 by the author. Licensee MDPI, Basel, Switzerland. This article is an open access article distributed under the terms and conditions of the Creative Commons Attribution (CC BY) license (https:// creativecommons.org/licenses/by/ $4.0 /)$.
Joint Research Centre (JRC), European Commission, 21027 Ispra, Italy; konstantinos.gkoumas@ec.europa.eu; Tel.: +39-0332-78-6041

\begin{abstract}
Hyperloop is a proposed very high-speed ground transportation system for both passenger and freight that has the potential to be revolutionary, and which has attracted much attention in the last few years. The concept was introduced in its modern form relatively recently, yet substantial progress has been made in the past years, with research and development taking place globally, from several Hyperloop companies and academics. This study examined the status of Hyperloop development and identified issues and challenges by means of a systematic review that analyzed 161 documents from the Scopus database on Hyperloop since 2014. Following that, a taxonomy of topics from scientific research was built under different physical and operational clusters. The findings could be of help to transportation academics and professionals who are interested in the developments in the field, and form the basis for policy decisions for the future implementation of Hyperloop.
\end{abstract}

Keywords: Hyperloop; vactrain; scientific research; taxonomy; technologies

\section{Introduction}

Mobility and transportation are among the most essential and important services to society. They encompass interconnected systems that are intended to cover the demand for mobility of people and goods. Transportation systems are intrinsically complex, including elements, both physical and organizational, that interact with and influence each other directly and indirectly, frequently in a nonlinear manner, and with the occurrence of feedback loops. [1]. According to this perspective, the transportation system is essentially a highly dynamic complex, large-scale, interconnected, open, socio-technical (CLIOS) system [2]. Nevertheless, present-day transportation modes (i.e., rail, road, air and waterborne transportation) are based on consolidated concepts, and improvements over the years have been essentially evolutionary, focusing on delivering a safe, efficient, reliable and accessible transportation system.

In the last decade, several transportation concepts and technologies have been identified as very promising. The impact of disruptive transportation technologies, i.e., those technologies with the potential to create disruptive innovation at industry and society level [3], has been an important area of research and development. In the transportation sector, information and communication technologies (ICT) and the Internet of Things (IoT) are bringing a revolution to the sector, with the advent of connected and automated road mobility being a notable example [4].

Hyperloop is one of those very promising and possibly disruptive future transportation technologies. Its development has received extensive media coverage over the last years following the Hyperloop Alpha white paper by Elon Musk published in 2013 [5]. Hyperloop consists of a system of tubes where vehicles (pods) travel at high speed (the original concept claims a top speed of $1220 \mathrm{~km} / \mathrm{h}$ ) in a low-pressure environment. Other than speed, Hyperloop's main advantage is that the partial vacuum lowers the air resistance (drag), thus, consuming less energy during acceleration and cruise [6]. An initial 
feasibility study published already in 2016 identifies research topics related to Hyperloop technologies [7].

After the white paper and the initial hype, several companies in the US brought together engineers and venture capital money to perform research and development and make Hyperloop a reality [8]. Later on, the same companies expanded to Europe, and other Europe-based companies engaged in similar activities [9], including the planning and development of Hyperloop test sites.

Furthermore, recent developments regarding the need for standardizationin Europe and the US highlight the interest in the regulation of Hyperloop. In Europe, the "Sustainable and Smart Mobility Strategy" was presented in December 2020 by the European Commission and the accompanying action plan of initiatives will guide its work for the next four years. Among the objectives of this plan is to "assess the need for regulatory actions to ensure safety and security of new technologies and concepts such as Hyperloop" [10]. Before that, a new Joint Technical Committee (TC), CEN/CLC/JTC 20, was launched by the European Committee for Standardization (CEN) and the European Committee for Electrotechnical Standardization (CENELEC) to address the need for the standardization of Hyperloop systems [11]. A year before, in 2019, the U.S. Department of Transportation (DOT) created the Non-Traditional and Emerging Transportation Technology (NETT) Council, an internal body with the objective of identifying and resolving gaps, either legal or regulatory, that may obstruct the deployment of Hyperloop, among other new technologies [12]. In January 2021, the NETT Council presented the "Hyperloop Standards Desk Review" with the scope of assessing the status of Hyperloop standardization activities, developing a foundation for future Hyperloop standardization efforts, and consequently, paving the way towards the development of a preliminary framework of Hyperloop system components and associated regulations and voluntary technical standards [13].

The dynamics of the technology and the progress made toward future Hyperloop deployment in Europe is highlighted by a recent mapping of activities in the industry and European institutions [14]. Nevertheless, to test the safety, efficiency and reliability of Hyperloop in the field, beyond research and development (R\&D), a long enough, full-scale prototype track is necessary.

Beyond the US and Europe, in China and Korea, as patent activity shows, there is substantial R\&D from CRRC Yangtze Co., the Korea Railroad Research Institute (KRRI) and the Korea Institute of Construction Technology (KICT) [14,15].

Considering the above, this study examines the status of Hyperloop scientific developments, identifying issues and challenges. It is based on initial considerations developed in [14]. Compared to that previous study, a systematic review was performed, and the fields of research were explicitly identified. Consequently, a taxonomy of scientific research issues was developed by analyzing all Hyperloop research in the literature, using the methodology developed by the European Commission's Transport Research and Innovation Monitoring and Information System (TRIMIS) [16]. Accordingly, the literature was organized in relevant clusters and for each cluster combination, the issues were identified as lower-level items in the taxonomy.

The findings could be of help to transportation academics and professionals who are interested in developments in the field, and form the basis for policy decisions for the future implementation of Hyperloop.

The paper consists of the following parts: after the introduction, the next section discusses the materials and methods used in this study, drawing from the Scopus database and a physical system decomposed into several clusters. Section 3 provides the results from the analyses grouped under the different clusters. Section 4 provides an initial taxonomy based on the performed analysis and a brief discussion. Section 5 provides the conclusions. 


\section{Materials and Methods}

The methodology presented in this section focuses on capturing research findings, aiming at the identification of trends, and consequently, building a taxonomy of issues. The Scopus database, which has scrupulous indexing rules, was used as a source.

For the analysis, the following steps were taken:

- A search using specific keywords ("Hyperloop" or "tube transport" or "vactrain") was carried out, in the abstract, title, or keywords. Results were limited to those published after 2013 (when the modern concept of Hyperloop was introduced), and documents from health sciences were excluded due to the lexical ambiguity of "Hyperloop transport" term. The exact query used was: TITLE-ABS-KEY ("Hyperloop" OR "tube transport" or "vactrain") AND PUBYEAR > 2013 and not SUBJAREA (MEDI OR NURS OR VETE OR DENT OR HEAL). This search performed in June 2021 resulted in 229 documents.

- An additional manual filtering of the documents one-by-one, on the basis of their title or abstract limited, resulted in 161 documents. The aim of this filtering was to eliminate those documents that were not relevant to the field due to lexical ambiguity and those that simply outlined Hyperloop-related aspects. This left 96 articles, 57 conference papers, three reviews, three notes, one letter and one book chapter.

Figure 1 shows the distribution of the documents over the considered time period.

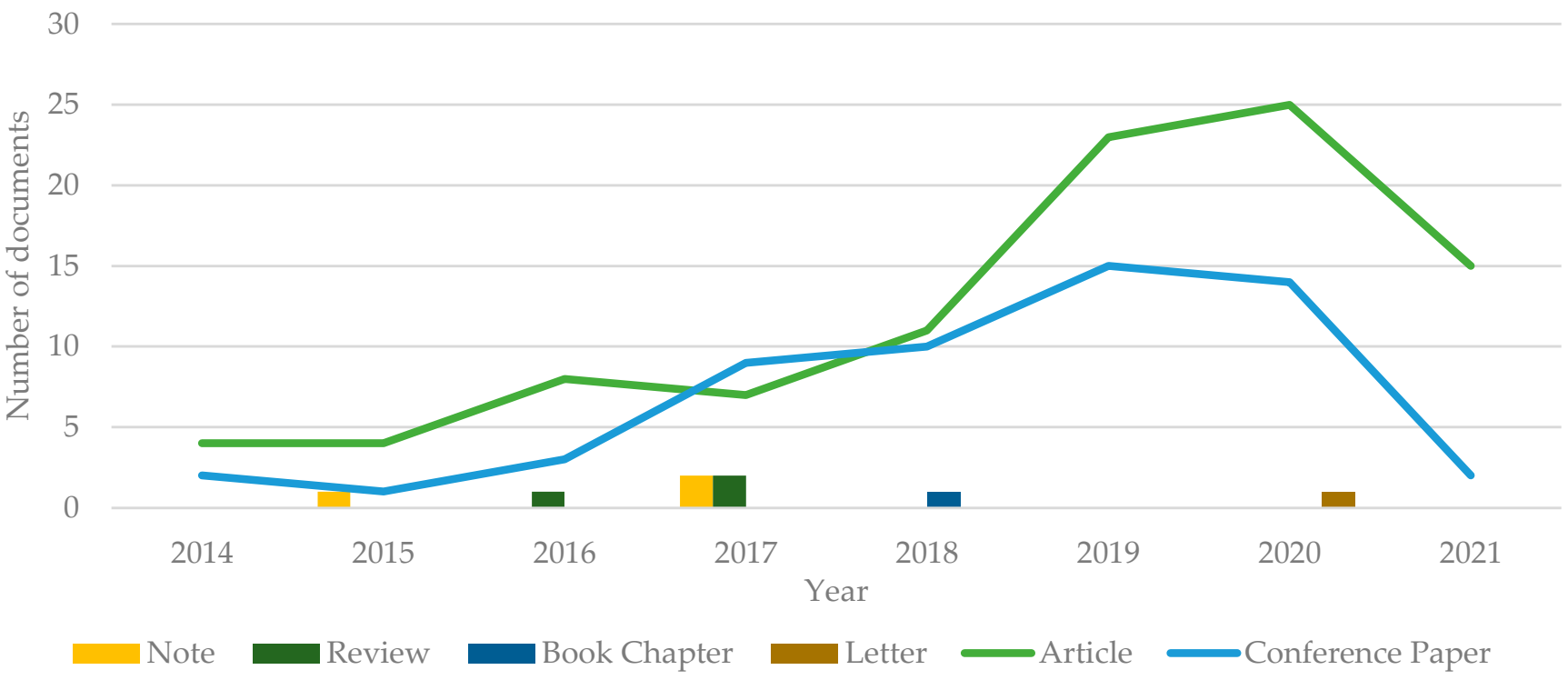

Figure 1. Evolution of Hyperloop academic research.

Figure 1 shows an overview of the results, which are destined to increase in 2021.

After this step, an analysis of all abstracts (and in case of doubt, of the full paper) took place, and the research was quantitatively assessed, focusing on several clusters. Inspired by the decomposition approach from [14], this was done by means of a system approach, breaking the Hyperloop system into five physical parts (Figure 2). These parts cover the entire hyperloop system, and outline interacting subsystems. 


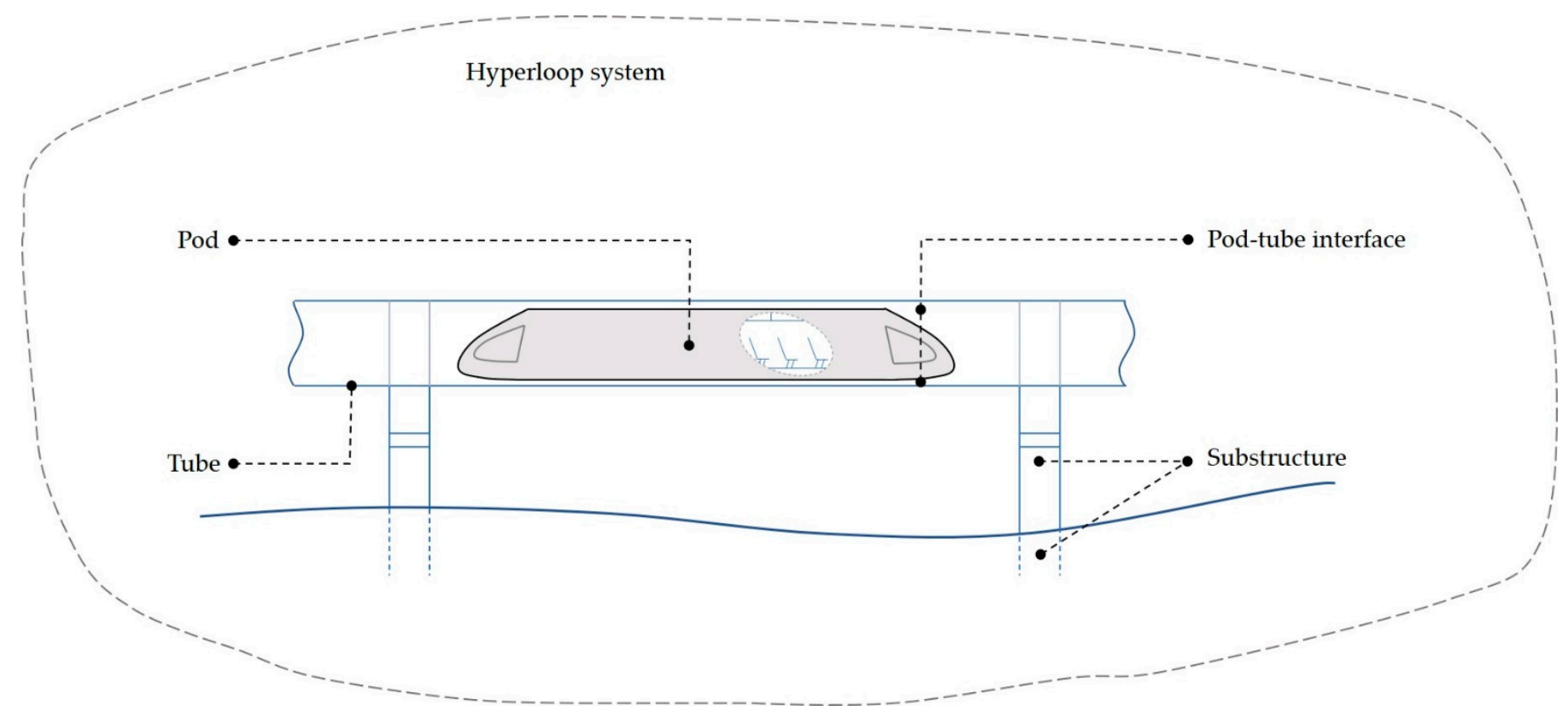

Figure 2. Hyperloop system decomposition (adapted from [14]).

The five physical clusters are:

- Hyperloop as a system: this includes research that encompasses the entire system and that cannot be considered under other disaggregated levels. Examples may include efficiency and energy studies of the system in operation.

- Substructure (including foundations and bridge work): focuses mostly on structural engineering design for the supporting structure.

- Tube: considers aspects related to the tube structure.

- Tube pod interface: focuses on research on the interface between the tube and the pod. Examples may include aerodynamic phenomena as a consequence of the pressure variation.

- Pod: focuses on aspects related to the pod (e.g., levitation, suspension, powertrain, electronics)

In addition, five horizontal (operational) clusters (energy, operations, communications, aerodynamics, safety) were considered.

It should be noted that this decomposition (into five physical and five horizontal clusters) while meaningful, is not the only one possible. In fact, in a design process it is impossible to decompose a system uniquely [17]. Nevertheless, this provides a rather generic and complete higher-level decomposition, which can be further broken down into lower hierarchies. For example, the "pod" cluster can be further decomposed into subclusters, covering the powertrain, the levitation and suspension blocks, etc. Likewise, the horizontal clusters can be further elaborated to cover additional operations. In this sense, the decomposition is scalable and provides the starting point for adding more elaborated layers of detail.

These clusters, although developed independently for this study, also encompass and are aligned with the priority work areas identified by the CEN/CENELEC TC on Hyperloop standardization, which include pressures of operation, door sealing, vehicletube interface, communication protocols and emergency evacuation [13].

Sections 3.1-3.5 present the results for the five physical clusters. In the analyses, each paper is also linked to one of the five horizonal clusters. Finally, Sections 3.6 and 3.7 present an overview of research involving general discussions and Hyperloop network developments. These last two, are not linked to the physical clusters since they focus on discussion rather than on the development of specific technologies. 


\section{Hyperloop Research Breakdown}

\subsection{Research on the Hyperloop System}

This section focuses on scientific research documents dealing with the Hyperloop system in general. Thirty-two papers were identified from the analysis.

An overview of the issues identified in the scientific literature under the five utility clusters is provided in Table 1.

Table 1. Issues identified in research on the Hyperloop system.

\begin{tabular}{|c|c|c|c|c|c|c|c|}
\hline Authors & Year & Issue & $\mathrm{E}$ & $\mathrm{O}$ & C & A & $\mathbf{S}$ \\
\hline Tavsanoglu et al. [18] & 2021 & Pod to ground wireless communication & & & $\mathrm{x}$ & & \\
\hline $\begin{array}{l}\text { Fernández Gago and } \\
\text { Collado Perez-Seoane [19] }\end{array}$ & 2021 & Geometric design and linear infrastructure planning & & $\mathrm{x}$ & & & \\
\hline Huang et al. [20] & 2021 & Optical wireless communication system & & & $\mathrm{x}$ & & \\
\hline Tbaileh et al. [21] & 2021 & Power requirements and impact on the electricity grid & $\mathrm{x}$ & & & & \\
\hline Han et al. [22] & 2020 & Wireless network architecture & & & $\mathrm{x}$ & & \\
\hline Brown et al. [23] & 2020 & Short-range communication & & & $\mathrm{x}$ & & \\
\hline Eichelberger et al. [24] & 2020 & Scheduling & & $\mathrm{x}$ & & & \\
\hline Zhang et al. [25] & 2020 & Pod to ground wireless communication & & & $\mathrm{x}$ & & \\
\hline Qiu et al. [26] & 2020 & Pod to ground wireless communication & & & $\mathrm{x}$ & & \\
\hline Janić [27] & 2020 & Energy consumption and $\mathrm{CO}_{2}$ emissions & $\mathrm{x}$ & & & & \\
\hline Lafoz et al. [28] & 2020 & Energy Storage Systems & $\mathrm{x}$ & & & & \\
\hline Zhang et al. [29] & 2020 & Pod to ground wireless communication & & & $\mathrm{x}$ & & \\
\hline Khan [30] & 2020 & Overall system development & & $\mathrm{x}$ & & & \\
\hline Narayan S. [31] & 2020 & Solar panel power & $\mathrm{x}$ & & & & \\
\hline Bempah et al. [32] & 2019 & Photovoltaic panel configurations for tube & $\mathrm{x}$ & & & & \\
\hline Huang et al. [33] & 2019 & Lateral drift under different low pressures & & $\mathrm{x}$ & & & \\
\hline Jin et al. [34] & 2019 & Dynamic characteristics under low-pressure & & $\mathrm{x}$ & & & \\
\hline Thakur et al. [35] & 2019 & Braking and deceleration & & & & & $\mathrm{x}$ \\
\hline Kim and Rho [36] & 2019 & Support facility and pods & & $\mathrm{x}$ & & & \\
\hline Dudnikov [37] & 2019 & Network operations & & $\mathrm{x}$ & & & \\
\hline Allen et al. [38] & 2019 & Pod to ground wireless communication & & & $\mathrm{x}$ & & \\
\hline Sutton [39] & 2019 & Process safety and generic safety cases & & & & & $\mathrm{x}$ \\
\hline Kauzinyte et al. [40] & 2019 & Simulation with aerodynamic constraints & & & & $\mathrm{x}$ & \\
\hline Deng et al. [41] & 2018 & System simulation & & $\mathrm{x}$ & & & \\
\hline Nikolaev et al. [42] & 2018 & Electric and software system & & $\mathrm{x}$ & & & \\
\hline Deng et al. [43] & 2017 & System simulation & & $\mathrm{x}$ & & & \\
\hline Janzen [44] & 2017 & Dynamic characteristics under low-pressure & & $\mathrm{x}$ & & & \\
\hline Kwon et al. [45] & 2017 & Photovoltaic panel configurations for tube & $\mathrm{x}$ & & & & \\
\hline Ali et al. [46] & 2017 & Handover algorithm & & & $\mathrm{x}$ & & \\
\hline Decker et al. [47] & 2017 & Conceptual feasibility study & & $\mathrm{x}$ & & & \\
\hline Zhou et al. [48] & 2016 & Energy consumption & $\mathrm{x}$ & & & & \\
\hline Brusyanin and Vikharev [49] & 2014 & Conceptual functional safety assessment & & & & & $x$ \\
\hline
\end{tabular}

Abbreviations: E: Energy; O: Operations; C: Communications; A: Aerodynamics; S: Safety.

\subsection{Research on Hyperloop Substructure}

This section focuses on scientific research documents dealing with the Hyperloop substructure. Eight papers were identified from the analysis.

An overview of the issues identified regarding Hyperloop substructure, under the five utility clusters, is provided in Table 2. 
Table 2. Issues identified in research on Hyperloop substructure.

\begin{tabular}{|c|c|c|c|c|c|c|c|}
\hline Authors & Year & Issue & $\mathrm{E}$ & $\mathbf{O}$ & $\mathrm{C}$ & A & S \\
\hline Museros et al. [50] & 2021 & Structural design & & & & & $x$ \\
\hline Zhao et al. [51] & 2021 & Vibration instability & & & & & $x$ \\
\hline Ahmadi et al. [52] & 2020 & Dynamic bridge deck-pier interaction & & & & & $x$ \\
\hline Ahmadi et al. [53] & 2020 & Dynamic amplification factors & & & & & $x$ \\
\hline Kemp et al. [54] & 2020 & Floating hyperloop tunnel conceptual design & & $x$ & & & \\
\hline Connolly and Costa [55] & 2020 & High speed dynamic load amplification & & $x$ & & & \\
\hline Alexander and Kashani [56] & 2018 & Bridge dynamics & & & & & $x$ \\
\hline Pegin et al. [57] & 2018 & Superstructure dynamic coefficients & & $x$ & & & \\
\hline
\end{tabular}

Abbreviations: E: Energy; O: Operations; C: Communications; A: Aerodynamics; S: Safety.

\subsection{Research on Hyperloop Tube Structure}

This section focuses on scientific research documents dealing with the Hyperloop tube structure. Seven papers were identified from the analysis.

An overview of the issues identified in regard to Hyperloop tube structure, under the five utility clusters, is provided in Table 3. As can be seen, the principal topic of research is the airtightness of concrete tubes.

Table 3. Issues identified in research on Hyperloop tube structure.

\begin{tabular}{|c|c|c|c|c|c|c|c|}
\hline Authors & Year & Issue & $\mathbf{E}$ & $\mathbf{O}$ & $\mathrm{C}$ & A & 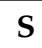 \\
\hline Devkota et al. [58] & 2021 & Concrete tube airtightness & & & & & $x$ \\
\hline Baek [59] & 2020 & Identification of anomalies in the tube & & & & & $x$ \\
\hline Devkota and Park [60] & 2019 & Concrete tube airtightness & & & & & $x$ \\
\hline Dudnikov [61] & 2018 & Concrete tube airtightness & & & & & $x$ \\
\hline Devkota et al. [62] & 2018 & Concrete tube airtightness & & & & & $x$ \\
\hline Choi et al. [63] & 2016 & Concrete tube airtightness & & & & & $x$ \\
\hline Park et al. [64] & 2015 & Concrete tube airtightness & & & & & $x$ \\
\hline
\end{tabular}

Abbreviations: E: Energy; O: Operations; C: Communications; A: Aerodynamics; S: Safety.

\subsection{Research on Hyperloop Tube-Pod Interface}

This section focuses on scientific research documents dealing with the Hyperloop tube-interface. Forty-eight papers were identified from the analysis.

An overview of the issues identified regarding the Hyperloop tube-pod interface, under the five utility clusters, is provided in Table 4.

Table 4. Issues identified in research on Hyperloop tube-pod interface.

\begin{tabular}{|c|c|c|c|c|c|c|c|}
\hline Authors & Year & Issue & $\mathbf{E}$ & $\mathbf{O}$ & $\mathrm{C}$ & A & $\mathbf{S}$ \\
\hline Bose and Viswanathan [65] & 2021 & Piston effect mitigation using airfoils & & & & $X$ & \\
\hline Lluesma-R. et al. [66] & 2021 & Use of compressor to mitigate aerodynamic drag & & & & $X$ & \\
\hline Zhou et al. [67] & 2021 & Radial gap and flow field & & & & $x$ & \\
\hline Hu et al. [68] & 2021 & Cross passage and flow field & & & & $x$ & \\
\hline Lluesma-R. et al. [69] & 2021 & $\begin{array}{l}\text { Drag coefficient effect on the aerodynamic } \\
\text { performance }\end{array}$ & & & & $x$ & \\
\hline Vakulenko et al. [70] & 2021 & Effect of external air exchange system & & & & $x$ & \\
\hline Uddin et al. [71] & 2021 & Drag-based aerodynamic braking & & & & & $x$ \\
\hline Huang et al. [72] & 2020 & Transient pressure on the tube & & & & $X$ & \\
\hline Galluzzi et al. [73] & 2020 & Stabilization of electrodynamic levitation systems & & $x$ & & & \\
\hline Nick and Sato [74] & 2020 & Pod structure aerodynamic optimization & & & & $X$ & \\
\hline Le et al. [75] & 2020 & Aerodynamic drag and pressure waves & & & & $x$ & \\
\hline Wang et al. [76] & 2020 & Blockage ratio and aerodynamic drag & & & & $x$ & \\
\hline Ma et al. [77] & 2020 & Air pressure and aerodynamic drag & & & & $x$ & \\
\hline Chen et al. [78] & 2020 & Structural mechanics properties of tube-wall & & $X$ & & & \\
\hline Jia et al. [79] & 2020 & Heat recycle duct and energy accumulation & $X$ & & & & \\
\hline
\end{tabular}


Table 4. Cont.

\begin{tabular}{|c|c|c|c|c|c|c|c|}
\hline Authors & Year & Issue & E & $\mathbf{O}$ & $\mathrm{C}$ & A & $\mathrm{S}$ \\
\hline Yang et al. [80] & 2020 & Blockage ratio and aerodynamic drag & & & & $x$ & \\
\hline Mao et al. [81] & 2020 & Vacuum level and heat transfer characteristics & $x$ & & & & \\
\hline Sui et al. [82] & 2020 & Blockage ratio and aerodynamic drag & & & & $X$ & \\
\hline Machaj et al. [83] & 2020 & Power consumption analysis & $X$ & & & & \\
\hline Zhang et al. [84] & 2019 & Guidance performance through curves & & $X$ & & & \\
\hline Strawa et al. [85] & 2019 & Pod in low-pressure environment & & $X$ & & & \\
\hline Nowacki et al. [86] & 2019 & Energy demand & $X$ & & & & \\
\hline Zhang et al. [87] & 2019 & Aerodynamic noise & & & & $X$ & \\
\hline Niu et al. [88] & 2019 & Aerodynamic heating & & & & $x$ & \\
\hline Oh et al. [89] & 2019 & Aerodynamics and blockage ration & & & & $x$ & \\
\hline Arun et al. [90] & 2019 & Conceptual aerodynamic design & & & & $x$ & \\
\hline Li et al. [91] & 2019 & Embarking and disembarking process & & $X$ & & & \\
\hline Wang and Yang [92] & 2019 & Electrodynamic magnetic levitation system & & $X$ & & & \\
\hline Chaidez et al. [93] & 2019 & Levitation methods power requirements & $X$ & & & & \\
\hline Jia et al. [94] & 2018 & $\begin{array}{l}\text { Aerodynamic characteristics and pressure recycle } \\
\text { ducts }\end{array}$ & & & & $x$ & \\
\hline Opgenoord and Caplan [95] & 2018 & Aerodynamic design & & & & $x$ & \\
\hline Zheng et al. [96] & 2018 & $\begin{array}{l}\text { High temperature superconducting magnetic } \\
\text { suspension }\end{array}$ & & $X$ & & & \\
\hline Wan et al. [97] & 2018 & Guidance performance through curves & & $X$ & & & \\
\hline Sayeed et al. [98] & 2018 & Magnetic levitation system prototype & & $X$ & & & \\
\hline Zhang et al. [99] & 2018 & Levitation force & & $x$ & & & \\
\hline Kang et al. [100] & 2017 & Aerodynamic drag parametric study & & & & $X$ & \\
\hline Zhou et al. [101] & 2017 & Energy consumption and blockage ratio & $X$ & & & & \\
\hline Braun et al. [102] & 2017 & Aerodynamic design multi-objective optimization & & & & $x$ & \\
\hline Heaton $[103]$ & 2017 & Inertial forces from earthquake & & & & & $x$ \\
\hline Opgenoord and Caplan [104] & 2017 & Aerodynamic design and boundary layer & & & & $x$ & \\
\hline Wang et al. [105] & 2017 & Aerodynamic design & & & & $x$ & \\
\hline Zhang et al. [106] & 2016 & Auxiliary pumping system & & $x$ & & & \\
\hline $\begin{array}{l}\text { Pekardan and Alexeenko } \\
\text { [107] }\end{array}$ & 2016 & Thermal lift generation and drag reduction & & & & $x$ & \\
\hline Braun et al. [108] & 2016 & Aerodynamic design and lift generation & & & & $x$ & \\
\hline Zhou et al. [109] & 2015 & Aerodynamics and thermal-pressure coupling & & & & $X$ & \\
\hline Zhou et al. [110] & 2014 & Entropy and aerodynamic heat generation & & & & $x$ & \\
\hline Ma et al. [111] & 2014 & Kinetic energy loss & & & & $x$ & \\
\hline Pandey and Mukherjea [112] & 2014 & Aerodynamic design & & & & $x$ & \\
\hline
\end{tabular}

Abbreviations: E: Energy; O: Operations; C: Communications; A: Aerodynamics; S: Safety.

\subsection{Research on Hyperloop Pod}

This section focuses on scientific research documents dealing with the Hyperloop pod. Twenty-seven papers were identified from the analysis.

An overview of the issues identified regarding the Hyperloop pod, under the five utility clusters, is provided in Table 5 .

Table 5. Issues identified in research on Hyperloop pod.

\begin{tabular}{|c|c|c|c|c|c|c|c|}
\hline Authors & Year & Issue & $\mathbf{E}$ & $\mathbf{O}$ & $\mathrm{C}$ & $\mathbf{A}$ & $\mathbf{S}$ \\
\hline Negash et al. [113] & 2021 & Semi-active suspension system & & $X$ & & & \\
\hline García-Tabarés et al. [114] & 2021 & Acceleration system based on a linear motor & & $x$ & & & \\
\hline Lim et al. [115] & 2020 & Electrodynamic suspension & & $x$ & & & \\
\hline Jayakumar et al. [116] & 2020 & Pod space frame & & $X$ & & & \\
\hline Lim et al. [117] & 2020 & High-temperature superconducting (HTS) magnet & & $x$ & & & \\
\hline Seo et al. [118] & 2020 & Propulsion/levitation/guidance LIM & & $x$ & & & \\
\hline Choi et al. [119] & 2019 & Sub-sonic linear synchronous motor & & $\mathrm{X}$ & & & \\
\hline Guo et al. [120] & 2019 & Null-flux coil electrodynamic suspension structure & & $X$ & & & \\
\hline Zheng et al. [121] & 2019 & Levitation and Linear Propulsion System & & $X$ & & & \\
\hline Seo et al. [122] & 2019 & Propulsion/levitation/guidance LIM & & $X$ & & & \\
\hline
\end{tabular}


Table 5. Cont.

\begin{tabular}{|c|c|c|c|c|c|c|c|}
\hline Authors & Year & Issue & $\mathbf{E}$ & $\mathbf{O}$ & C & A & $\mathbf{S}$ \\
\hline Tudor and Paolone [123] & 2019 & Influence of batteries to the propulsion & $x$ & & & & \\
\hline Bhuiya et al. [124] & 2019 & Three-phase inverter for powertrain & & $X$ & & & \\
\hline Naik et al. [125] & 2019 & Cold Gas Propulsion System & & $X$ & & & \\
\hline Guo et al. [126] & 2019 & Electrodynamic suspension & & $X$ & & & \\
\hline Cho et al. [127] & 2019 & Propulsion/levitation/guidance LIM & & $X$ & & & \\
\hline Indraneel et al. [128] & 2019 & Levitation & & $X$ & & & \\
\hline Soni et al. [129] & 2019 & Magnetic brakes & & & & & $\mathrm{x}$ \\
\hline Tudor and Paolone [130] & 2019 & Propulsion system and energy requirements & $X$ & & & & \\
\hline Ji et al. [131] & 2018 & Propulsion/levitation/guidance LIM & & $X$ & & & \\
\hline Abdelrahman et al. [132] & 2018 & Magnetic levitation & & $x$ & & & \\
\hline Pradhan and Katyayan [133] & 2018 & Vehicle dynamics & & $X$ & & & \\
\hline Klim and Hashemi [134] & 2017 & Vehicle wheels design & & $X$ & & & \\
\hline Zhou et al. [135] & 2016 & Propulsion/levitation/guidance LIM & & $X$ & & & \\
\hline Ma et al. [136] & 2015 & Electromagnetic braking & & & & & $x$ \\
\hline Chin et al. [137] & 2015 & Pod sizing & & $X$ & & & \\
\hline Zhang [138] & 2014 & Life support systems & & & & & $x$ \\
\hline
\end{tabular}

Abbreviations: E: Energy; O: Operations; C: Communications; A: Aerodynamics; S: Safety; LIM: Linear Induction Motor.

\subsection{Discussion Papers on Hyperloop}

This section focuses on scientific research documents that focus on general discussions.

Thirty papers were identified from the analysis.

Table 6 provides an overview of the topics discussed.

Table 6. General discussion papers.

\begin{tabular}{|c|c|c|}
\hline Authors & Year & Issue \\
\hline Noland [139] & 2021 & Systematic technology review \\
\hline Hansen [140] & 2020 & Technology assessment \\
\hline Gieras [141] & 2020 & Technical/technological aspects \\
\hline Sutar et al. [142] & 2020 & Hyperloop concept \\
\hline Gkoumas and Christou [14] & 2020 & Policy and technical context \\
\hline Barbosa [143] & 2020 & Technology review \\
\hline Kumar et al. [144] & 2019 & Technical/technological aspects \\
\hline Janić [145] & 2019 & Technical/technological/policy aspects \\
\hline Lipusch et al. [146] & 2019 & Financing \\
\hline Deng et al. [147] & 2019 & Technical/technological aspects \\
\hline Bersano and Fayemi [148] & 2019 & Innovation management and design theory \\
\hline Leibowicz [149] & 2018 & Technical/technological/policy aspects \\
\hline van Goeverden et al. [150] & 2018 & Performance compared to air and high-speed train \\
\hline Melzer and Zech [151] & 2018 & Social media \\
\hline Ahmad et al. [152] & 2017 & Preliminary patent analysis \\
\hline Kerns [153] & 2017 & Hyperloop competitions \\
\hline Violette [154] & 2017 & Hyperloop competitions \\
\hline Dudnikov [155] & 2017 & Tube and pod technical parameters \\
\hline (No author name available) [156] & 2017 & Hyperloop competitions \\
\hline Halsmer et al. [157] & 2017 & Hyperloop competitions \\
\hline González-G. and Nogués [158] & 2017 & Technical/technological aspects \\
\hline González-G. and Nogués [159] & 2017 & Technical/technological aspects \\
\hline Bradley [160] & 2016 & Development cases \\
\hline Rubin [161] & 2016 & Development cases \\
\hline Anyszewski [162] & 2016 & Competitions \\
\hline Ross [163] & 2016 & Hyperloop concept \\
\hline Palacin [164] & 2016 & Viewpoint \\
\hline Thompson [165] & 2015 & Social aspects \\
\hline Abaffy [166] & 2015 & Financing \\
\hline Kosowatz [167] & 2014 & Viability \\
\hline
\end{tabular}




\subsection{Research on Hyperloop Networks}

This section focuses on scientific research documents that focus on the development of Hyperloop networks. Ten papers were identified from the analysis.

Table 7 provides an overview of the topics discussed.

Table 7. Network papers.

\begin{tabular}{lll}
\hline Authors & Year & Issue \\
\hline Merchant and Chankov [168] & 2020 & Scenario analysis in Europe \\
Neef et al. [169] & 2020 & Scenario analysis on infrastructure networks \\
Bertolotti and Occa [170] & 2020 & Agent-based model of supply chain system \\
Rajendran and Harper [171] & 2020 & Define, Measure, Analyze, Design, and Verify (DMADV) approach \\
Cho [172] & 2019 & Implications at local level \\
Pfoser et al. [173] & 2018 & Hyperloop and synchromodality \\
Voltes-Dorta and Becker [174] & 2018 & Implications at local level \\
Markvica et al. [175] & 2018 & Hyperloop impact in Europe \\
Schodl et al. [176] & 2018 & Large scale regional impact \\
Werner et al. [177] & 2016 & Implications at local level (cargo) \\
\hline
\end{tabular}

The relationship between vertical and decomposition clusters in the documents is shown in the chord diagram of Figure 3. The 30 documents on Hyperloop discussions and the 10 documents on Hyperloop network developments are excluded from the diagram. The left part of the figure reports the utility clusters and, on the right, the physical clusters. Visualizations of this kind highlight the most popular research topics and the relationship between them, and help to identify research insufficiencies.

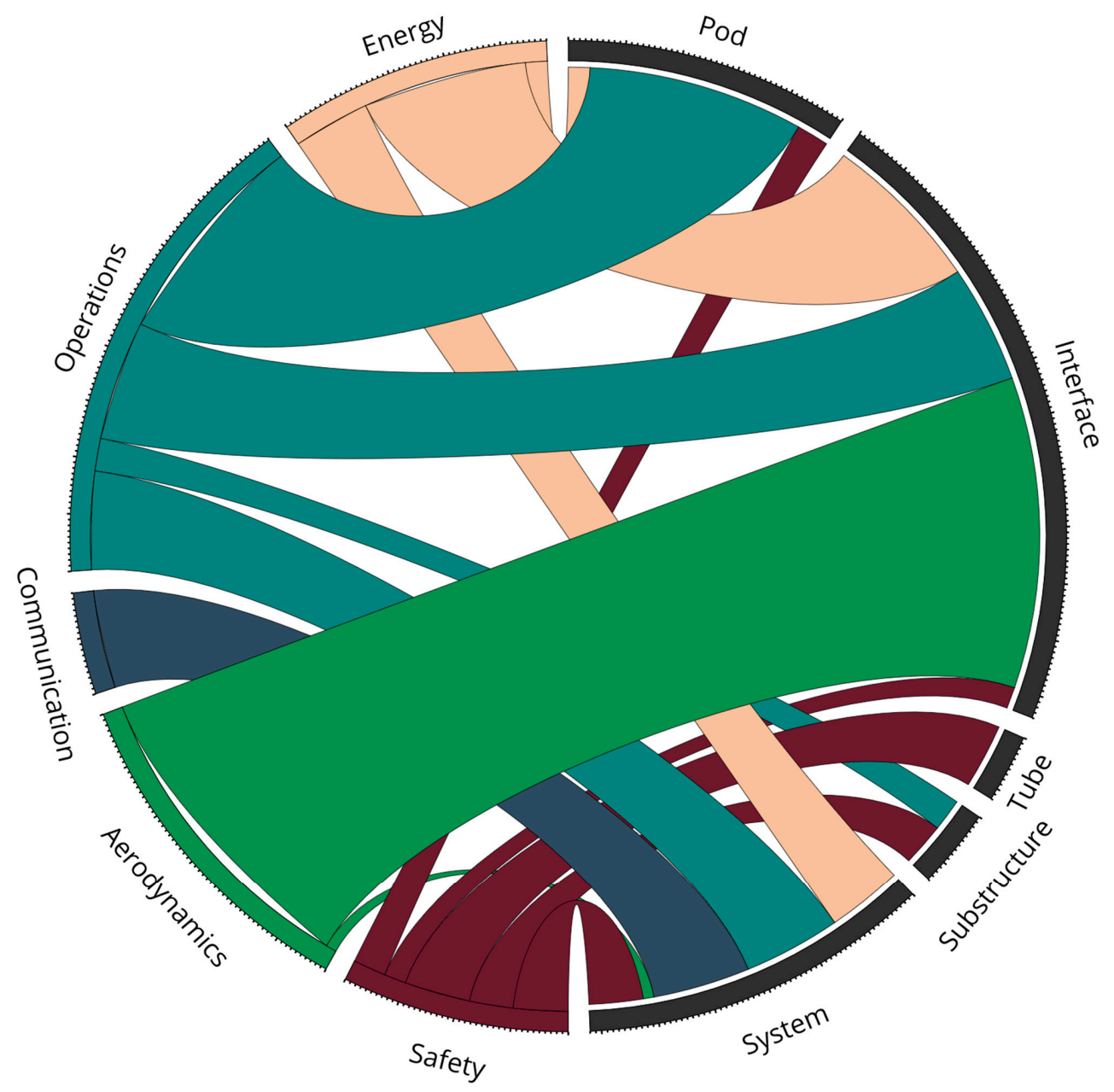

Figure 3. Hyperloop academic research clusters relation overview. 
As can be seen, and with regard to the physical decomposition, the majority of research focuses on the pod-tube interface and aerodynamics (29 documents) and the pod and operations (21 documents). Communication technologies were researched in nine documents at a system level. The 21 documents focusing explicitly on safety issues, cover all horizontal areas.

\section{Initial Taxonomy of Issues}

The next step was to build a preliminary taxonomy of research topics. As explained in Section 3, all papers were read and grouped under the different clusters. Each paper was also flagged for the respective research issues. Table 8 aggregates the findings from the 161 documents. For the utility clusters, an overview of the emerging issues is reported, while for the physical and generic clusters, the research issues are reported in detail, aggregating the identified issues from Section 3. It should be noted that the obtained taxonomy is not unique, and further readings could identify additional elements.

Table 8. A taxonomy of overarching research clusters and research issues on Hyperloop arising from the scientific literature analysis.

\begin{tabular}{|c|c|c|c|}
\hline & & Research Clusters & Researched Issues \\
\hline \multirow{5}{*}{$\begin{array}{l}\text { Utility cluster } \\
\text { overview }\end{array}$} & 1 & Energy & Energy consumption (may include aerodynamics, but focuses on heat dissipation) \\
\hline & 2 & Safety & Safety process, evacuation, pod tightness, breaking \\
\hline & 3 & Communications & Pod-to-pod and pod-to-ground communication \\
\hline & 4 & Aerodynamics & Aerodynamic phenomena \\
\hline & 5 & Operations & Hyperloop operations and research not covered in utility clusters $1-4$ \\
\hline \multirow{5}{*}{$\begin{array}{l}\text { Physical } \\
\text { clusters }\end{array}$} & A & System & $\begin{array}{l}\text { Optical wireless communication, pod-to-ground communication, communication } \\
\text { signal propagation, system simulation, functional safety, process safety, safety } \\
\text { cases, energy storage systems, lateral drift, energy consumption, network } \\
\text { architecture, scheduling, short range communication, power requirements, impact } \\
\text { on the electricity grid, short-range communication, scheduling, electric and } \\
\text { software system, photovoltaic panels, handover algorithm, geometric design, } \\
\text { linear infrastructure planning }\end{array}$ \\
\hline & B & Substructure & $\begin{array}{l}\text { Structural design, bridge dynamics, geotechnical, earthquake, resonant dynamic } \\
\text { effects, vibration instability, bridge deck-pier interaction, bridge dynamics, } \\
\text { dynamic amplification factors, dynamic load amplification, floating Hyperloop } \\
\text { tunnel }\end{array}$ \\
\hline & $\mathrm{C}$ & Tube & Airtightness, anomaly detection \\
\hline & $\mathrm{D}$ & Tube-pod interface & $\begin{array}{l}\text { Levitation friction, aerodynamic drag, blockage ratio, vacuum effects, piston effect } \\
\text { mitigation, heat generation, tube/pod combined design, energy loss, aerodynamic } \\
\text { noise, levitation force, kinetic energy, pressure recycle ducts, aerodynamic } \\
\text { breaking }\end{array}$ \\
\hline & $\mathrm{E}$ & Pod & $\begin{array}{l}\text { Motor, propulsion, semi-active suspension, electrodynamic suspension, levitation, } \\
\text { guidance, design, sizing, battery, tightness, Linear Induction Motor, } \\
\text { high-temperature superconducting (HTS) magnet, batteries, wheel design, } \\
\text { additive manufacturing, inverter for powertrain, Cold Gas Propulsion }\end{array}$ \\
\hline \multirow[t]{2}{*}{$\begin{array}{l}\text { Generic } \\
\text { clusters }\end{array}$} & $\mathrm{i}$ & Discussion & $\begin{array}{l}\text { Technical feasibility, financing, policy recommendations, new mobility paradigms, } \\
\text { knowledge management, technology overview, education, competitions, general } \\
\text { feasibility }\end{array}$ \\
\hline & ii & Network & $\begin{array}{l}\text { Network feasibility, financial efficiency, network simulations, network operations, } \\
\text { scenario analysis, synchromodality, supply chain, regional impact }\end{array}$ \\
\hline
\end{tabular}

A variety of researched topics emerges from Table 8.

The Hyperloop as a system cluster (A) includes a lot of research on different operational aspects, in particular communications. In fact, this aspect appears to be challenging at very high speeds in tunnel structures. Some other aspects related to the geometric design and the linear infrastructure development are also covered in this cluster in an analytical manner.

The Hyperloop substructure cluster (B) includes a great deal of research from the fields of structural and bridge engineering. The major difference is the dynamic loads 
imposed by the Hyperloop pods, which influence the design of substructure and need to be accounted for.

Some research deficiencies were identified. This is the case for research focusing on the Hyperloop tube cluster (C), and consequently, on infrastructure. Considering that infrastructure costs are high (especially for a new system) the lack of research in this area (e.g., materials, tube thickness) is visible.

At the same time, Hyperloop tube-pod interface cluster (D) research focuses on a variety of issues linked in particular to aerodynamic performance under low pressure.

Research focusing on the Hyperloop pod cluster (E) covers many aspects that are linked to the powertrain, suspension, magnetic levitation and guidance. A number of similarities with high-speed rail and (especially) magnetic levitation (Maglev) trains are apparent, something that may lead to research spillovers from the two transport modes.

Finally, the rather high number of discussion papers and those related to Hyperloop networks highlight the overall interest in Hyperloop as a transport mode.

\section{Conclusions}

Hyperloop is a proposed very high-speed ground transportation system that has great potential for the decarbonization of transportation, and it has received a great deal of attention from transportation academics. This study aimed to provide a baseline with regard to the topics and challenges identified in the scientific research, for the effective testing and deployment of Hyperloop. The presentation of the issues follows a structured methodology, and provides insights for future research. In particular, the adopted clustering is scalable, and consequently, more detailed sub-clusters could be easily identified. The performed extensive literature review, to the authors' knowledge, is the most complete of its kind.

As discussed in the previous section, based on the detailed findings and the taxonomy of issues identified under the overarching clusters, there is vast interest from the research community on this topic.

These findings could play an important role in providing input to ongoing Hyperloop standardization processes by looking into the different approaches for solving specific issues. The findings also complement proprietary technologies developed by Hyperloop promoters, since in many cases, academic research on the same topics is independent. Therefore, it can provide a fresh perspective since academic research follows different paths of knowledge compared to industry. This is more evident in specific clusters (e.g., substructure and tube) where structural engineering approaches are implemented, relying on the long-standing expertise of researchers in the specific field.

Another possible use that emerges is the opportunity to compare the taxonomy with research issues in legacy systems, e.g., high speed rail. In this way, it is possible to quickly check (a) similarities in the research in the two systems, and consequently, possible research spillovers, and (b) research issues not yet explored. The results from such an exercise could provide valuable input to standardization and certification bodies.

The findings could ignite policy initiatives focusing on future decisions regarding the Hyperloop. For this process to succeed, the continuous identification and assessment of issues will be necessary, including challenges beyond technology (e.g., social aspects, project financing), which will help to make the demonstration and deployment of Hyperloop possible. Outside policymaking, this paper helps academics and professionals who are interested in the development of Hyperloop technologies by providing digested information on scientific developments in this area.

Future research could focus on expanding this taxonomy to cover other domains of knowledge, in particular, intellectual property applications from Hyperloop promoters and nationally funded research.

Funding: This research received no external funding.

Informed Consent Statement: Not applicable. 
Data Availability Statement: Scopus data were used in the analyses.

Acknowledgments: Michalis Christou is acknowledged for fruitful discussion on the topic. The views expressed here are purely those of the author and may not, under any circumstances, be regarded as an official position of the European Commission. This research is based on data available from or elaborated by the Joint Research Centre (JRC) TRIMIS team (the European Commission's Transport Research and Innovation Monitoring and Information System-https://trimis.ec.europa.eu, accessed on 20 June 2021). The Joint Research Centre is in charge of the development of TRIMIS, and the work has been carried out under the supervision of the Directorate-General for Mobility and Transport (DG MOVE) and the Directorate-General for Research and Innovation (DG RTD) that are co-leading the Strategic Transport Research and Innovation Agenda (STRIA).

Conflicts of Interest: No conflict of interest. Outside policymaking.

\section{References}

1. Cascetta, E.; Pagliara, F.; Papola, A. Governance of Urban Mobility: Complex Systems and Integrated Policies. Adv. Complex. Syst. 2007, 10, 339-354. [CrossRef]

2. Dodder, R.; Sussman, J.; McConnell, J. The Concept of the "CLIOS PROCESS": Integrating the Study of Physical and Policy Systems Using Mexico City as an Example. In Proceedings of the Engineering Systems Division Symposium, Cambridge, MA, USA, 29-31 March 2004.

3. Millar, C.; Lockett, M.; Ladd, T. Disruption: Technology, innovation and society. Technol. Forecast. Soc. Chang. 2018, 129, 254-260. [CrossRef]

4. Alonso Raposo, M.; Ciuffo, B.; Alves Dies, P.; Ardente, F.; Aurambout, J.-P.; Baldini, G.; Baranzelli, C.; Blagoeva, D.; Bobba, S.; Braun, R.; et al. The Future of Road Transport-Implications of Automated, Connected, Low-Carbon and Shared Mobility; Publications Office of the European Union: Luxembourg, 2019; ISBN 978-92-76-14318-5.

5. Space-X. Hyperloop Alpha. 2013. Available online: https://www.spacex.com/sites/spacex/files/hyperloop_alpha-20130812.pdf (accessed on 20 June 2021).

6. Riviera, M. High-Speed Trains Comparison to Hyperloop: Energy, Sustainability and Safety Analysis Hyperloop Integrations to Reach the NOAH Concept. Master's Thesis, Politecnico di Torino, Torino, Italy, 2018.

7. Taylor, C.L.; Hyde, D.J.; Barr, L.C. Hyperloop Commercial Feasibility Analysis: High Level Overview; John A. Volpe National Transportation System Center: Cambridge, MA, USA, 2016.

8. Davies, A. The WIRED Guide to Hyperloop -Everything You Ever Wanted to Know about Elon Musk's Fever-Dream Train-in-aTube. 2018. Available online: https:/ / www.wired.com/story / guide-hyperloop (accessed on 20 June 2021).

9. Mawad, M.; Palmer, M. The Europeans Building Musk's Hyperloop Vision. 2020. Available online: https://sifted.eu/articles/ european-hyperloop (accessed on 20 June 2021).

10. European Commission. Sustainable and Smart Mobility Strategy—Putting European Transport on Track for the Future; COM/2020/789; European Commission: Brussels, Belgium, 2020.

11. CEN-CENELEC. A Newcomer in the European Transport Standardization Family: JTC 20 on Hyperloop Systems. 2020. Available online: https:/ / www.cencenelec.eu/news/articles/Pages / AR-2020-003.aspx (accessed on 20 June 2021).

12. US Department of Transportation. NETT Council. Available online: https://www.transportation.gov/nettcouncil (accessed on 25 March 2021).

13. US Department of Transportation. Hyperloop Standards Desk Review. Available online: https://www.transportation.gov/ policy-initiatives/nett/hyperloop-standards-desk-review (accessed on 25 March 2021).

14. Gkoumas, K.; Christou, M. A Triple-Helix Approach for the Assessment of Hyperloop Potential in Europe. Sustainability 2020, 12, 7868. [CrossRef]

15. Spencer, J.; Whitfield, I. Which Companies Are Filing Hyperloop Patents? Reddie \& Grose. 2020. Available online: https: //www.reddie.co.uk/2020/11/24/which-companies-are-filing-hyperloop-patents/ (accessed on 25 March 2021).

16. Tsakalidis, A.; Gkoumas, K.; Grosso, M.; Pekár, F. TRIMIS: Modular Development of an Integrated Policy-Support Tool for Forward-Oriented Transport Research and Innovation Analysis. Sustainability 2020, 12, 194. [CrossRef]

17. Pahl, G.; Beitz, W.; Feldhusen, J.; Grote, K.H. (Eds.) Engineering Design: A Systematic Approach, 3rd ed.; Springer: Berlin/Heidelberg, Germany, 2007.

18. Tavsanoglu, A.; Briso, C.; Carmena-Cabanillas, D.; Arancibia, R.B. Concepts of Hyperloop Wireless Communication at 1200 km/h: 5G, Wi-Fi, Propagation, Doppler and Handover. Energies 2021, 14, 983. [CrossRef]

19. Fernández Gago, J.Á.; Collado Pérez-Seoane, F. Methodology for the Characterisation of Linear Rail Transport Infrastructures with the Machine Learning Technique and Their Application in a Hyperloop Network. Urban. Rail Transit. 2021. [CrossRef]

20. Huang, X.; Yang, F.; Song, J.; Han, Z. An Optical Communication Approach for Ultra-High-Speed Train Running in Evacuated Tube: Potentials and Challenges. IEEE Wirel. Commun. 2021, 1-7. [CrossRef]

21. Tbaileh, A.; Elizondo, M.; Kintner-Meyer, M.; Vyakaranam, B.; Agrawal, U.; Dwyer, M.; Samaan, N.A. Modeling and Impact of Hyperloop Technology on the Electricity Grid. IEEE Trans. Power Syst. 2021, 1. [CrossRef] 
22. Han, L.; Wu, H.; Chen, X. Wireless network architecture for evacuated tube transportation system. China Commun. 2020, 17, 206-217. [CrossRef]

23. Brown, T.W.C.; Allen, B.H.; Drysdale, T.D.; Dagia, U.K. Linear angular momentum multiplexing-Conceptualization and experimental evaluation with antenna arrays. Proc. R. Soc. A Math. Phys. Eng. Sci. 2020, 476, 20200209. [CrossRef]

24. Eichelberger, M.; Geiter, D.T.; Schmid, R.; Wattenhofer, R. High-Throughput and Low-Latency Hyperloop*. In Proceedings of the 2020 IEEE 23rd International Conference on Intelligent Transportation Systems (ITSC), Rhodes, Greece, 20-23 September 2020; pp. 1-6.

25. Zhang, J.; Liu, L.; Han, B.; Li, Z.; Zhou, T.; Wang, K.; Wang, D.; Ai, B. Concepts on Train-to-Ground Wireless Communication System for Hyperloop: Channel, Network Architecture, and Resource Management. Energies 2020, 13, 4309. [CrossRef]

26. Qiu, C.; Liu, L.; Han, B.; Zhang, J.; Li, Z.; Zhou, T. Broadband Wireless Communication Systems for Vacuum Tube High-Speed Flying Train. Appl. Sci. 2020, 10, 1379. [CrossRef]

27. Janić, M. Estimation of direct energy consumption and $\mathrm{CO}_{2}$ emission by high speed rail, transrapid maglev and hyperloop passenger transport systems. Int. J. Sustain. Transp. 2020, 1-22. [CrossRef]

28. Lafoz, M.; Navarro, G.; Blanco, M.; Torres, J. Energy Storage Systems for Power Supply of Ultrahigh Speed Hyperloop Trains. In Ibero-American Congress of Smart Cities; Nesmachnow, S., Hernández Callejo, L., Eds.; Springer: Cham, Switzerland, 2020; Volume 1152. [CrossRef]

29. Zhang, J.; Liu, L.; Wang, K.; Han, B.; Piao, Z.; Wang, D. Analysis of the Effective Scatters for Hyperloop Wireless Communications Using the Geometry-Based Model. In Machine Learning for Cyber Security; Chen, X., Yan, H., Yan, Q., Zhang, X., Eds.; Springer: Cham, Switzerland, 2020; Volume 12487. [CrossRef]

30. Khan, M.M. Development of Ryerson's Hyperloop Pod Systems Using a Modular Approach BT. In Proceedings of the International Conference on Aerospace System Science and Engineering 2019, Toronto, ON, Canada, 30 July-1 August 2019; Jing, Z., Ed.; Springer: Singapore, 2020; pp. 209-218.

31. Narayan, S. Solar-powered vactrain-A preliminary analysis. In Proceedings of the Canadian Transportation Research Forum 51st Annual Conference-North American Transport Challenges in an Era of Change, Toronto, ON, Canada, 1-4 May 2016.

32. Bempah, K.O.; Kwon, K.; Kim, K.A. Experimental study of photovoltaic panel mounting configurations for tube-shaped structures. Appl. Energy 2019, 240, 754-765. [CrossRef]

33. Huang, Z.; Lei, W.; Bao, S.; Qian, N.; Zheng, J.; Deng, Z. Lateral drift of the HTS Maglev vehicle running on a ring test line under low pressure environment. Phys. C Supercond. Appl. 2019, 565. [CrossRef]

34. Jin, L.; Deng, Z.; Lei, W.; Li, H.; Li, J.; Qian, N. Dynamic Characteristics of the HTS Maglev Vehicle Running Under a Low-Pressure Environment. IEEE Trans. Appl. Supercond. 2019, 29. [CrossRef]

35. Thakur, H.; Rastogi, A.; Singh, R.R.; Khanduri, S. Braking/deceleration mechanism in hyperloop system using sensor values and feedback. Int. J. Recent Technol. Eng. 2019, 7, 160-163.

36. Kim, D.; Rho, H. Study on the analysis of capsule vehicle and support facility scale for hyper-tube system operations. J. Korean Soc. Railw. 2019, 22, 641-648. [CrossRef]

37. Dudnikov, E.E. Structure of Hyperloop Systems with Intermediate Station. In Proceedings of the Twelfth International Conference "Management of Large-Scale System Development" (MLSD), Moscow, Russia, 1-3 October 2019; pp. 1-3. [CrossRef]

38. Allen, B.H.; Brown, T.W.C.; Drysdale, T.D. A new paradigm for train to ground connectivity using angular momentum. In Proceedings of the IEEE 5G World Forum 5GWF 2019 Conference, Dresden, Germany, 30 September-2 October 2019; pp. 185-188. [CrossRef]

39. Sutton, I. Process Safety and the Hyperloop; Institution of Chemical Engineers: Ashland, VA, USA, 2019.

40. Kauzinyte, G.; Vezza, M.; Alizadeh, S.; Eckford, D. Hyperloop: Simulation and Assessment of High-Speed Vehicle Transport in Evacuated Tubes; BHR Group Limited, University of Glasgow: Glasgow, UK, 2019; pp. 61-76.

41. Deng, Z.; Zheng, J.; Sun, R.; Liao, H.; Zheng, X.; Zhang, J. Recent Activities of HTS Maglev in ASCLab. In Proceedings of the 2018 IEEE International Conference on Applied Superconductivity and Electromagnetic Devices (ASEMD), Tianjing, China, 15-18 April 2018; pp. 1-2. [CrossRef]

42. Nikolaev, R.; Idiatuallin, R.; Nikolaeva, D. Software System in Hyperloop Pod. Procedia Comput. Sci. 2018, 126, 878-890. [CrossRef]

43. Deng, Z.; Zhang, W.; Zheng, J.; Wang, B.; Ren, Y.; Zheng, X.; Zhang, J. A High-Temperature Superconducting Maglev-Evacuated Tube Transport (HTS Maglev-ETT) Test System. IEEE Trans. Appl. Supercond. 2017, 27. [CrossRef]

44. Janzen, R. TransPod Ultra-High-Speed Tube Transportation: Dynamics of Vehicles and Infrastructure. Procedia Eng. 2017, 199, 8-17. [CrossRef]

45. Kwon, K.; Yeom, J.; Kim, K.A. Photovoltaic Panel Orientation Study for Tube-Enclosed Transportation Systems. In Proceedings of the 2017 IEEE 3rd International Future Energy Electronics Conference and ECCE Asia (IFEEC 2017-ECCE Asia), Kaohsiung, Taiwan, 3-7 June 2017; pp. 1149-1154. [CrossRef]

46. Ali, W.; Wang, J.; Zhu, H.; Wang, J. An Expedited Predictive Distributed Antenna System Based Handover Scheme for High-Speed Railway. In Proceedings of the GLOBECOM 2017-2017 IEEE Global Communications Conference, Singapore, 4-8 December 2017; pp. 1-6. [CrossRef]

47. Decker, K.; Chin, J.; Peng, A.; Summers, C.; Nguyen, G.; Oberlander, A.; Sakib, G.; Sharifrazi, N.; Heath, C.; Gray, J.; et al. Conceptual Feasibility Study of the Hyperloop Vehicle for Next-Generation Transport. In Proceedings of the 55th AIAA Aerospace Sciences Meeting, Grapevine, TX, USA, 9-13 January 2017. [CrossRef] 
48. Zhou, Y.; Liu, H.; Jia, W.; Li, Q. Modeling and simulation of total energy consumption in evacuated tube transportation. Zhenkong Kexue Yu Jishu Xuebao J. Vac. Sci. Technol. 2016, 36, 1301-1305. [CrossRef]

49. Brusyanin, D.; Vikharev, S. The basic approach in designing of the functional safety index for transport infrastructure. Contemp. Eng. Sci. 2014, 7, 287-292. [CrossRef]

50. Museros, P.; Lázaro, C.; Pinazo, B.; Monleón, S. Key aspects in the analysis and design of Hyperloop ${ }^{\mathrm{TM}}$ infrastructure under static, dynamic and thermal loads. Eng. Struct. 2021, 239, 112177. [CrossRef]

51. Zhao, M.; de Oliveira Barbosa, J.M.; Yuan, J.; Metrikine, A.V.; van Dalen, K.N. Instability of vibrations of an oscillator moving at high speed through a tunnel embedded in soft soil. J. Sound Vib. 2021, 494, 115776. [CrossRef]

52. Ahmadi, E.; Alexander, N.A.; Kashani, M.M. Lateral dynamic bridge deck-pier interaction for ultra-high-speed Hyperloop train loading. Proc. Inst. Civil Eng. Bridge Eng. 2020, 173, 198-206. [CrossRef]

53. Ahmadi, E.; Kashani, M.M.; Alexander, N.A. Dynamic amplification factors for ultra-high-speed hyperloop trains: Vertical and lateral vibrations. In Proceedings of the EURODYN 2020, XI International Conference on Structural Dynamics, Athens, Greece, 23-26 November 2020; Volume 2. [CrossRef]

54. Kemp, L.J.; Otto, W.J.; Waals, O.J. Conceptual Design and Model Tests for a Mid-Water Floating Hyperloop Tunnel. In Proceedings of the ASME 2020 39th International Conference on Ocean, Offshore and Arctic Engineering, Virtual, online. 3-7 August 2020; American Society of Mechanical Engineers Digital Collection: New York, NY, USA, 2020.

55. Connolly, D.P.; Costa, P.A. Geodynamics of very high speed transport systems. Soil Dyn. Earthq. Eng. 2020, 130. [CrossRef]

56. Alexander, N.A.; Kashani, M.M. Exploring Bridge Dynamics for Ultra-high-speed, Hyperloop, Trains. Structures 2018, 14, 69-74. [CrossRef]

57. Pegin, P.; Igolkin, G.; Rajczyk, M. A model for dynamic design of a superstructure for magnetic levitation vehicles. Transp. Res. Procedia 2018, 36, 567-576. [CrossRef]

58. Devkota, P.; Jang, H.W.; Hong, J.-W.; Park, J. Finite Element Analysis-Based Damage Metric for Airtightness Performance Evaluation of Concrete Tube Structures. KSCE J. Civ. Eng. 2021, 25, 1385-1398. [CrossRef]

59. Baek, J. Two-Dimensional LiDAR Sensor-Based Three-Dimensional Point Cloud Modeling Method for Identification of Anomalies inside Tube Structures for Future Hypersonic Transportation. Sensors 2020, 20, 7235. [CrossRef]

60. Devkota, P.; Park, J. Analytical model for air flow into cracked concrete structures for super-speed tube transport systems. Infrastructures 2019, 4, 76. [CrossRef]

61. Dudnikov, E.E. The Problem of Ensuring the Tightness in Hyperloop Passenger Systems. In Proceedings of the 2018 Eleventh International Conference Management of large-Scale System Development (MLSD), Moscow, Russia, 1-3 October 2018; pp. 1-4. [CrossRef]

62. Devkota, P.; Park, J.; Choi, E. Effect of cracks on air-tightness of vacuum tube bridge structures. In Maintenance, Safety, Risk, Management and Life-Cycle Performance of Bridges; CRC Press: Boca Raton, FL, USA, 2018; ISBN 9781315189390.

63. Choi, J.; Han, O.; Park, J. Development of Air Inflow Model for Airtightness Performance Evaluation of Concrete Tube Structures with Cracks. In Proceedings of the 4th International Conference on Sustainable Construction Materials and Technologies, SCMT 2016, Las Vegas, NV, USA, 7-11 August 2016.

64. Park, C.-H.; Cheon, D.-S.; Park, J. Analytical Model of Fluid Flow through Closed Structures for Vacuum Tube Systems. Math. Probl. Eng. 2015, 2015. [CrossRef]

65. Bose, A.; Viswanathan, V.K. Mitigating the Piston Effect in High-Speed Hyperloop Transportation: A Study on the Use of Aerofoils. Energies 2021, 14, 464. [CrossRef]

66. Lluesma-Rodríguez, F.; González, T.; Hoyas, S. CFD Simulation of a Hyperloop Capsule Inside a Low-Pressure Environment Using an Aerodynamic Compressor as Propulsion and Drag Reduction Method. Appl. Sci. 2021, 11, 3934. [CrossRef]

67. Zhou, K.; Ding, G.; Wang, Y.; Niu, J. Aeroheating and aerodynamic performance of a transonic hyperloop pod with radial gap and axial channel: A contrastive study. J. Wind Eng. Ind. Aerodyn. 2021, 212, 104591. [CrossRef]

68. Hu, X.; Deng, Z.; Zhang, W. Effect of cross passage on aerodynamic characteristics of super-high-speed evacuated tube transportation. J. Wind Eng. Ind. Aerodyn. 2021, 211, 104562. [CrossRef]

69. Lluesma-Rodríguez, F.; González, T.; Hoyas, S. CFD simulation of a hyperloop capsule inside a closed environment. Results Eng. 2021, 9, 100196. [CrossRef]

70. Vakulenko, S.; Larin, O.; Bokov, A.; Korytova, M. Mathematical Simulations of Air Exchange Processes in Evacuated Tube Transport. Transp. Res. Procedia 2021, 54, 584-593. [CrossRef]

71. Uddin, M.R.; Saniat, T.S.; Salehin, S.; Rahman, M.H. Drag-based aerodynamic braking system for the Hyperloop: A numerical study. Trans. Can. Soc. Mech. Eng. 2020, 45, 1-10. [CrossRef]

72. Huang, Z.; Chang, N.; Yang, T. Transient Pressure on Tube-Wall in Evacuated Tube Transportation: A Simulation and Experimental Study. Chin. J. Vac. Sci. Technol. 2020, 12, 1182-1190.

73. Galluzzi, R.; Circosta, S.; Amati, N.; Tonoli, A.; Bonfitto, A.; Lembke, T.A.; Kertész, M. A Multi-domain Approach to the Stabilization of Electrodynamic Levitation Systems. J. Vib. Acoust. Trans. Asme 2020, 142. [CrossRef]

74. Nick, N.; Sato, Y. Computational fluid dynamics simulation of Hyperloop pod predicting laminar-turbulent transition. Railw. Eng. Sci. 2020, 28, 97-111. [CrossRef]

75. Le, T.T.G.; Jang, K.S.; Lee, K.-S.; Ryu, J. Numerical Investigation of Aerodynamic Drag and Pressure Waves in Hyperloop Systems. Mathematics 2020, 8, 1973. [CrossRef] 
76. Wang, J.; Zhang, Y.; Hu, X.; Wang, P.; Li, H.; Deng, Z. Aerodynamic Characteristics of High-Temperature Superconducting Maglev-Evacuated Tube Transport. In Proceedings of the 2020 IEEE International Conference on Applied Superconductivity and Electromagnetic Devices (ASEMD), Tianjin, China, 16-18 October 2020; pp. 1-2. [CrossRef]

77. Ma, T.; Wang, B.; Hu, X.; Wang, J.; Rao, Y.; Zheng, J.; Deng, Z. Aerodynamic Drag Characteristics of the HTS Maglev Vehicle Running in a Low Air-Pressure Tube. In Proceedings of the 2020 IEEE International Conference on Applied Superconductivity and Electromagnetic Devices (ASEMD), Tianjin, China, 16-18 October 2020; pp. 1-2. [CrossRef]

78. Chen, R.; Sun, Z.; Lv, Q.; Yang, Z. Characterization of Structural Mechanics of Vacuum-Tube with Lab-Built Simulator: An Experimental Study. Chin. J. Vac. Sci. Technol. 2020, 9, 818-826.

79. Jia, W.; Zhang, K.; Wang, C.; Yan, J.; Liu, Z.; Li, Q. Study on the influence of HRD on aerodynamic heat diffusion of VTT system under different blocking ratios. Vacuum 2020, 179, 109502. [CrossRef]

80. Yang, Y.; Qiang, G.; Peng, X. Aerodynamic Characteristics and Change Rules of Vehicle Piston Wind in Evacuated Tube. J. Hunan Univ. Nat. Sci. 2020, 47, 24-31.

81. Mao, Y.; Yang, M.; Wang, T.; Wu, F.; Qian, B. Influence of vacuum level on heat transfer characteristics of maglev levitation electromagnet module. Appl. Sci. 2020, 10, 1106. [CrossRef]

82. Sui, Y.; Niu, J.; Yuan, Y.; Yu, Q.; Cao, X.; Wu, D.; Yang, X. An Aerothermal Study of Influence of Blockage Ratio on a Supersonic Tube Train System. J. Sci. 2020. [CrossRef]

83. Machaj, K.; Malecha, Z.; Wrzecioniarz, P. Numerical and analytical study of a battery powered vehicle moving in a vacuum tunnel. World Electr. Veh. J. 2020, 11, 26. [CrossRef]

84. Zhang, W.; Deng, Z.; Zhang, Y.; Wang, H.; Zheng, J.; Shi, Y.; Zhou, D.; Cardwell, D.A. Magnetic levitation and guidance performance of $\mathrm{Y}-\mathrm{Ba}-\mathrm{Cu}-\mathrm{O}$ and Gd-Ba-Cu-O bulk superconductors under low ambient pressure. J. Phys. D Appl. Phys. 2019, 52. [CrossRef]

85. Strawa, N.; Malczyk, P. Modeling and control of a simplified high-speed vehicle moving in reduced-pressure conditions. Arch. Mech. Eng. 2019, 66, 355-377. [CrossRef]

86. Nowacki, M.; Olejniczak, D.; Markowski, J. Assessment of medium parameters in a closed space for a Hyperloop transport capsule with reference to reducing the energy demand of a transport system. E3s Web Conf. 2019, 108. [CrossRef]

87. Zhang, K.R.; Li, Q.L.; Wang, C.W.; Jia, W.G. Aerodynamic noises of vacuum tube transportation: A simulation and theoretical study. Chin. J. Vac. Sci. Technol. 2019, 39, 950-956.

88. Niu, J.; Sui, Y.; Yu, Q.; Cao, X.; Yuan, Y. Numerical study on the impact of Mach number on the coupling effect of aerodynamic heating and aerodynamic pressure caused by a tube train. J. Wind Eng. Ind. Aerodyn. 2019, 190, 100-111. [CrossRef]

89. Oh, J.S.; Kang, T.; Ham, S.; Lee, K.S.; Jang, Y.J.; Ryou, H.S.; Ryu, J. Numerical analysis of aerodynamic characteristics of Hyperloop system. Energies 2019, 12, 518. [CrossRef]

90. Arun, S.B.; Majumder, A.; Anveeth, B.H.; Tomar, A.; Dhar, A. Conceptual Design of a Hyperloop Pod Traveling at High Speed Inside a Vacuum Tube. In Proceedings of the 10th International Conference on Advances in Computing, Control, and Telecommunication Technologies, ACT 2019, Hyderabad, India, 25-26 July 2019; pp. 57-61.

91. Li, D.; van der Vegte, W.F.; Geuze, M.; van der Meijs, M.; Mastrigt, S.H.-V. Studying a new embarking and disembarking process for future hyperloop passengers. In Proceedings of the 20th Congress of the International Ergonomics Association (IEA 2018), Florence, Italy, 26-30 August 2018; Advances in Intelligent Systems and Computing. Bagnara, S., Tartaglia, R., Albolino, S., Alexander, T., Fujita, Y., Eds.; Springer: Cham, Switzerland, 2019; Volume 823, pp. 217-229. [CrossRef]

92. Wang, R.; Yang, B. A transient Model of Inductrack Dynamic Systems. In Proceedings of the ASME 2019 International Design Engineering Technical Conferences and Computers and Information in Engineering Conference, IDETC-CIE 2019, Anaheim, CA, USA, 18-21 August 2019. [CrossRef]

93. Chaidez, E.; Bhattacharyya, S.P.; Karpetis, A.N. Levitation methods for use in the hyperloop high-speed transportation system. Energies 2019, 12, 4190. [CrossRef]

94. Jia, W.; Wang, K.; Cheng, A.; Kong, X.; Cao, X.; Li, Q. Air flow and differential pressure characteristics in the vacuum tube transportation system based on pressure recycle ducts. Vacuum 2018, 150, 58-68. [CrossRef]

95. Opgenoord, M.M.J.; Caplan, P.C. Aerodynamic design of the Hyperloop concept. AIAA J. 2018, 56, 4261-4270. [CrossRef]

96. Zheng, L.H.; Li, X.Q.; Jin, J.X. Conceptual Models of Levitated HTS Linear Drive. In Proceedings of the IEEE International Conference on Applied Superconductivity and Electromagnetic Devices, ASEMD 2018, Tianjin, China, 15-18 April 2018. [CrossRef]

97. Wan, L.; Zhang, Y.; Zheng, B.; Zheng, J.; Deng, Z. Guidance Performance of YBCO Bulks Under a Low-Pressure Environment. In Proceedings of the 2018 IEEE International Conference on Applied Superconductivity and Electromagnetic Devices (ASEMD), Tianjin, China, 15-18 April 2018; pp. 1-2. [CrossRef]

98. Sayeed, J.M.; Abdelrahman, A.; Youssef, M.Z. Hyperloop Transportation System: Control, and Drive System Design. In Proceedings of the 2018 IEEE Energy Conversion Congress and Exposition (ECCE), Portland, OR, USA, 23-27 September 2018; Volume 65, pp. 2767-2773. [CrossRef]

99. Zhang, Y.; Zheng, J.; Zheng, B.; Liu, X.; Wang, H.; Deng, Z. Levitation Force of Bulk YBaCuO and GdBaCuO Under a Low-Pressure Environment. IEEE Trans. Appl. Supercond. 2018, 28, 1-5. [CrossRef]

100. Kang, H.; Jin, Y.; Kwon, H.; Kim, K. A study on the aerodynamic drag of transonic vehicle in evacuated tube using computational fluid dynamics. Int. J. Aeronaut. Sp. Sci. 2017, 18, 614-622. [CrossRef] 
101. Zhou, Y.; Jia, W.; Wang, K.; Liu, H.; Li, Q. Analysis of Energy Consumption in the ETT System Based on Blockaging Ratio. Zhenkong Kexue Yu Jishu Xuebao J. Vac. Sci. Technol. 2017, 37, 131-136. [CrossRef]

102. Braun, J.; Sousa, J.; Pekardan, C. Aerodynamic design and analysis of the hyperloop. AIAA J. 2017, 55, 4053-4060. [CrossRef]

103. Heaton, T.H. Inertial forces from earthquakes on a hyperloop pod. Bull. Seism. Soc. Am. 2017, 107, 2521-2524. [CrossRef]

104. Opgenoord, M.M.J.; Caplan, P.C. On the Aerodynamic Design of the Hyperloop Concept. In Proceedings of the 35th AIAA Applied Aerodynamics Conference, Denver, CO, USA, 5-9 June 2017. [CrossRef]

105. Wang, H.; Yang, Y.; Coleman, D.; Benedict, M. Aerodynamic Simulation of High-Speed Capsule in the Hyperloop System. In Proceedings of the 35th AIAA Applied Aerodynamics Conference, Denver, CO, USA, 5-9 June 2017. [CrossRef]

106. Zhang, Y. Proposal of auxilary pumping technique: Taking-in and pushing-out low-pressure air with running vehicle in vacuum tube transport. Zhenkong Kexue Yu Jishu Xuebao J. Vac. Sci. Technol. 2016, 36, 760-766. [CrossRef]

107. Pekardan, C.; Alexeenko, A. Thermal Lift Generation and Drag Reduction in Rarefied Aerodynamics; AIP Conference Proceedings: College Park, MD, USA, 2016; Volume 1786, p. 190002. [CrossRef]

108. Braun, J.; Sousa, J.; Pekardan, C. Aerodynamic design and analysis of the hyperloop. In Proceedings of the 52nd AIAA/SAE/ASEE Joint Propulsion Conference, Salt Lake City, UT, USA, 25-27 July 2016. [CrossRef]

109. Zhou, Y.; Liu, H.; Liu, Y.; Jia, W.; Li, Q. Simulation of aerodynamic characteristics of evacuated tube transportation based on similarity theoretics. Zhenkong Kexue Yu Jishu Xuebao J. Vac. Sci. Technol. 2015, 35, 1105-1111. [CrossRef]

110. Zhou, Y.; Liu, H.; Liu, Y.; Duan, R.; Li, Q. Simulation of entropy layer in evacuated tube transport at supersonic speed. Zhenkong Kexue Yu Jishu Xuebao J. Vac. Sci. Technol. 2014, 34, 775-780. [CrossRef]

111. Ma, J.; Zhou, D.; Zhao, L.; Zhang, Y.; Zhao, Y. The energy loss of running high-temperature superconducting maglev train for the vibration in evacuated tube. Zhenkong Kexue Yu Jishu Xuebao J. Vac. Sci. Technol. 2014, 34, 119-125. [CrossRef]

112. Pandey, B.K.; Mukherjea, S.K. Aerodynamic simulation of evacuated tube transport trains with suction at tail. In Proceedings of the ASME 2014 International Mechanical Engineering Congress and Exposition, IMECE 2014, Montreal, QC, Canada, 14-20 November 2014. [CrossRef]

113. Negash, B.A.; You, W.; Lee, J.; Lee, C.; Lee, K. Semi-active control of a nonlinear quarter-car model of hyperloop capsule vehicle with Skyhook and Mixed Skyhook-Acceleration Driven Damper controller. Adv. Mech. Eng. 2021, 13, 1687814021999528. [CrossRef]

114. García-Tabarés, L.; Lafoz, M.; Torres, J.; Soriano, G.; Orient, D.; Fons, D. Analysis of Alternatives for the Acceleration of a Hyperloop System. In Ibero-American Congress of Smart Cities; Nesmachnow, S., Hernández Callejo, L., Eds.; Springer: Cham, Switzerland, 2021; Volume 1359. [CrossRef]

115. Lim, J.; Lee, C.-Y.; Lee, J.-H.; You, W.; Lee, K.-S.; Choi, S. Design Model of Null-Flux Coil Electrodynamic Suspension for the Hyperloop. Energies 2020, 13, 5075. [CrossRef]

116. Jayakumar, V.; Indraneel, T.S.; Chawla, R.; Mohanty, S.; Shetty, S.; Shiyani, D.; Abdallah, S. Verification and validation for a finite element model of a hyperloop pod space frame. In Proceedings of the 37th IMAC, A Conference and Exposition on Structural Dynamics, Orlando, FL, USA, 28-31 January 2019. [CrossRef]

117. Lim, J.; Lee, C.Y.; Choi, S.; Lee, J.H.; Lee, K.S. Design optimization of a 2G HTS magnet for subsonic transportation. IEEE Trans. Appl. Supercond. 2020, 30. [CrossRef]

118. Seo, K.Y.; Park, C.B.; Jeong, G.; Lee, J.B.; Kim, T.; Lee, H.W. A study on the design of propulsion/levitation/guidance integrated DSLIM with non-symmetric structure. AIP Adv. 2020, 10. [CrossRef]

119. Choi, S.Y.; Lee, C.Y.; Jo, J.M.; Choe, J.H.; Oh, Y.J.; Lee, K.S.; Lim, J.Y. Sub-sonic linear synchronous motors using superconducting magnets for the hyperloop. Energies 2019, 12, 4611. [CrossRef]

120. Guo, Z.; Li, J.; Zhou, D. Study of a null-flux coil electrodynamic suspension structure for evacuated tube transportation. Symmetry 2019, 11, 1239. [CrossRef]

121. Zheng, L.H.; Li, X.Q.; Wang, A.G. Conceptual Models of HTS Levitation and Linear Propulsion System. IEEE Trans. Appl. Supercond. 2019, 29. [CrossRef]

122. Seo, K.-Y.; Park, C.-B.; Jeong, G.; Kim, S.-H.; Lee, H.-W. A study on the design of propulsion/levitation/guidance integrated DSLIM for application to hyperloop. J. Korean Soc. Railw. 2019, 22, 872-879. [CrossRef]

123. Tudor, D.; Paolone, M. Influence of battery models on the optimal design of the propulsion system of a hyperloop capsule. In Proceedings of the 2019 IEEE Vehicle Power and Propulsion Conference (VPPC), Hanoi, Vietnam, 14-17 October 2019; pp. 1-7. [CrossRef]

124. Bhuiya, M.A.; Ashraf, M.; Haniff, A.; Okorie, E.; Kofoalada, S.; Koraz, Y.; Youssef, M.Z. Evaluation and Design of a Three-Phase Inverter for a Maglev Application. In Proceedings of the 2019 IEEE Conference on Power Electronics and Renewable Energy (CPERE), Aswan, Egypt, 23-25 October 2020; pp. 418-424. [CrossRef]

125. Naik, P.M.; Darekar, B.J.; Unde, J.S.; Dhamangaokar, P.R. Cold Gas Propulsion System for Hyperloop Pod Chassis. J. Phys. Conf. Ser. 2019, 1276. [CrossRef]

126. Guo, Z.; Zhou, D.; Chen, Q.; Yu, P.; Li, J. Design and analysis of a plate type electrodynamic suspension structure for ground high speed systems. Symmetry 2019, 11, 1117. [CrossRef]

127. Cho, H.-T.; Liu, Y.-C.; Kim, K.A. Short-Primary Linear Induction Motor Modeling with End Effects for Electric Transportation Systems. In Proceedings of the 4th International Symposium on Computer, Consumer and Control, IS3C 2018, Taichung City, Taiwan, 6-8 December 2018; pp. 338-341. [CrossRef] 
128. Indraneel, T.S.; Jayakumar, V.; Soni, A.; Shiyani, D.; Tyagi, K.; Abdallah, S. Levitation Array Testing for Hyperloop pod Design. In Proceedings of the AIAA Scitech Forum, San Diego, CA, USA, 7-11 January 2019. [CrossRef]

129. Soni, A.; Indraneel, T.S.; Jayakumar, V.; Shiyani, D.; Bhagwat, P.; Abdallah, S. Magnetic brake testing for hyperloop pod design. In Proceedings of the AIAA Scitech Forum, San Diego, CA, USA, 7-11 January 2019. [CrossRef]

130. Tudor, D.; Paolone, M. Optimal Design of the Propulsion System of a Hyperloop Capsule. IEEE Trans. Transp. Electrif. 2019, 5 , 1406-1418. [CrossRef]

131. Ji, W.-Y.; Jeong, G.; Park, C.-B.; Jo, I.-H.; Lee, H.-W. A Study of Non-Symmetric Double-Sided Linear Induction Motor for Hyperloop All-In-One System (Propulsion, Levitation, and Guidance). IEEE Trans. Magn. 2018, 54. [CrossRef]

132. Abdelrahman, A.S.; Sayeed, J.; Youssef, M.Z. Hyperloop Transportation System: Analysis, Design, Control, and Implementation. IEEE Trans. Ind. Electron. 2018, 65, 7427-7436. [CrossRef]

133. Pradhan, R.; Katyayan, A. Vehicle dynamics of permanent-magnet levitation based hyperloop capsules. In Proceedings of the ASME 2018 Dynamic Systems and Control Conference, DSCC 2018, Atlanta, GA, USA, 30 September-3 October 2018. [CrossRef]

134. Klim, G.; Hashemi, S.M. Designing Mass-Optimized parts using solid thinking inspire with application to the hyperloop deployable wheel system. In Proceedings of the 76th SAWE International Conference on Mass Properties Engineering, Montreal, QC, Canada, 20-25 May 2017.

135. Zhou, D.; Cui, C.; Ma, J.; Zhao, L.; Zhang, Y.; Zhao, Y. Starting characteristics of linear motor in evacuated tube HTS sidesuspended maglev system. Xinan Jiaotong Daxue Xuebao J. Southwest Jiaotong Univ. 2016, 51, 750-758. [CrossRef]

136. Ma, J.; Zhou, D.; Zhao, L.; Liang, G.; Zhang, Y.; Zhao, Y. Electromagnetic braking of high temperature superconducting maglev train traveling in evacuated tube transport. Zhenkong Kexue Yu Jishu Xuebao J. Vac. Sci. Technol. 2015, 35, 130-136. [CrossRef]

137. Chin, J.C.; Gray, J.S.; Jones, S.M.; Berton, J.J. Open-Source Conceptual Sizing Models for the Hyperloop Passenger Pod. In Proceedings of the 6th AIAA/ASCE/AHS/ASC Structures, Structural Dynamics, and Materials Conference 2015, Kissimmee, FL, USA, 5-9 January 2015. [CrossRef]

138. Zhang, Y.P. Main Technologies of Life Support System of Evacuated Tube Transportation Vehicle Passenger Cabin. AMM 2014, 599-601, 616-621. [CrossRef]

139. Nøland, J.K. Prospects and Challenges of the Hyperloop Transportation System: A Systematic Technology Review. IEEE Access 2021, 9, 28439-28458. [CrossRef]

140. Hansen, I.A. Hyperloop transport technology assessment and system analysis. Transp. Plan. Technol. 2020, 43, 803-820. [CrossRef]

141. Gieras, J.F. Ultra high-speed ground transportation systems: Current Status and a vision for the future. Przeglad Elektrotechniczny 2020, 1-7. [CrossRef]

142. Sutar, A.V.; Raut, S.V.; Kulkarni, R.K.; Shingte, S.H. Hyperloop System Implementation using Magnetic Levitation Principle. In Proceedings of the 4th International Conference on Intelligent Computing and Control Systems (ICICCS), Madurai, India, 13-15 May 2020; pp. 979-983. [CrossRef]

143. Barbosa, F.C. Hyperloop Concept Technological and Operational Review: The Potential to Fill Rail Niche Markets. In Proceedings of the 2020 Joint Rail Conference, St. Louis, MO, USA, 20-22 April 2020. [CrossRef]

144. Kumar, S.D.; Namdeo, U.; Samadhiya, A.; Mishra, P.; Dinesh Krishna, K. Hyper loop transportation system. Int. J. Innov. Technol. Explor. Eng. 2019, 8, 2637-2641.

145. Janić, M. Future advanced long-haul Evacuated Tube Transport (EET) system operated by TransRapid Maglev (TRM): A multidimensional examination of performance. Transp. Plan. Technol. 2019, 42, 130-151. [CrossRef]

146. Lipusch, N.; Dellermann, D.; Ebel, P.; Bretschneider, U.; Leimeister, J.M. Radically rethinking the way crowdfunding works: The case of JumpStartFund and the Hyperloop. Int. J. Entrep. Ventur. 2019, 11, 598-619. [CrossRef]

147. Deng, Z.; Zhang, Y.; Wang, B.; Zhang, W. Present Situation and Prospect of Evacuated Tube Transportation System. Xinan Jiaotong Daxue Xuebao J. Southwest Jiaotong Univ. 2019, 54, 1063-1072. [CrossRef]

148. Bersano, G.; Fayemi, P.-E. Application of TRIZ and Innovation Management Theory on Decision Support for Transport Infrastructure. In Proceedings of the 19th International TRIZ Future Conference on Automated Invention for Smart Industries, TFC 2019, Marrakesh, Morocco, 9-11 October 2019; Volume 572, pp. 486-493. [CrossRef]

149. Leibowicz, B.D. Policy recommendations for a transition to sustainable mobility based on historical diffusion dynamics of transport systems. Energy Policy 2018, 119, 357-366. [CrossRef]

150. Van Goeverden, K.; Milakis, D.; Janic, M.; Konings, R. Analysis and modelling of performances of the HL (Hyperloop) transport system. Eur. Transp. Res. Rev. 2018, 10. [CrossRef]

151. Melzer, J.; Zech, B. How social media influencers enabled a B2B company to drive awareness and engagement with their target consumers. J. Brand Strat. 2018, 7, 110-116.

152. Ahmad, O.; Ali, M.N.; Chekima, A. Advances in zero energy transportation systems. J. Eng. 2017, 3, 1537-1543. [CrossRef]

153. Kerns, J. How did a reddit thread turn into a hyperloop super-team? Mach. Des. 2017, 89, 62-68.

154. Violette, M. The kids are alright: University of Maryland's hyperloop team. IEEE Electromagn. Compat. Mag. 2017, 6, 22-23. [CrossRef]

155. Dudnikov, E.E. Advantages of a New Hyperloop Transport Technology. In Proceedings of the 2017 Tenth International Conference Management of Large-Scale System Development (MLSD), Moscow, Russia, 2-4 October 2017; pp. 1-4. [CrossRef]

156. Hyperloop One completes second test phase. Reinf. Plast. 2017, 61, 305. [CrossRef] 
157. Halsmer, D.M.; Leland, R.P.; Dzurilla, E. A Laboratory-Based Course in Systems Engineering Focusing on the Design of a High-Speed Mag-Lev Pod for the Space X Hyperloop Competition. In Proceedings of the 2017 ASEE Annual Conference \& Exposition, Columbus, OH, USA, 24-28 June 2017. [CrossRef]

158. González-González, E.; Nogués, S. Railways of the future: Evolution and prospects of high-speed rail, maglev and hyperloop (2nd part). DYNA 2017, 92, 483-485. [CrossRef]

159. González-González, E.; Nogués, S. Railways of the future: Evolution and prospects of high-speed, maglev and hyperloop (1st part). DYNA 2017, 92, 371-373. [CrossRef]

160. Bradley, R. The unbelievable reality of the impossible hyperloop. Technol. Rev. 2016, 119, 38-47.

161. Rubin, D.K. Top 500: Hyperloop designs start to unfold. ENR 2016, 275.

162. Anyszewski, A. Edinburgh's hyperloop team predicts a transport revolution. Proc. Inst. Civ. Eng. Civ. Eng. 2016, 170, 51. [CrossRef]

163. Ross, P.E. Hyperloop: No pressure: The vacuum train project will get its first test track this year. IEEE Spectr. 2016, 53, 51-54. [CrossRef]

164. Palacin, R. Hyperloop, the electrification of mobility, and the future of rail travel [Viewpoint]. IEEE Electrif. Mag. 2016, 4, 4-51. [CrossRef]

165. Thompson, C. The hyperloop will be only the latest innovation that's pretty much a series of tubes: The idea of using pneumatics to send objects has been around for ages. But people? Smithsonian 2015, 2015.

166. Abaffy, L. SpaceX gets big investment for satellite internet and hyperloop test track announced. ENR $2015,274$.

167. Kosowatz, J. Investigating hyperloop's viability. Mech. Eng. 2014, 136, 12-15.

168. Merchant, D.V.; Chankov, S.M. Towards a European Hyperloop Network: An Alternative to Air and Rail Passenger Travel. In Proceedings of the 2020 IEEE International Conference on Industrial Engineering and Engineering Management (IEEM), Singapore, 14-17 December 2020; pp. 128-132. [CrossRef]

169. Neef, R.; Verweij, S.; Busscher, T.; Arts, J. A common ground? Constructing and exploring scenarios for infrastructure network-ofnetworks. Futures 2020, 124, 102649. [CrossRef]

170. Bertolotti, F.; Occa, R. "Roads? Where We're Going We Don't Need Roads." Using Agent-Based Modeling to Analyze the Economic Impact of Hyperloop Introduction on a Supply Chain. In Multi-Agent Systems and Agreement Technologies; EUMAS 2020, AT 2020; Lecture Notes in Computer Science; Bassiliades, N., Chalkiadakis, G., de Jonge, D., Eds.; Springer: Cham, Switzerland, 2020; Volume 12520. [CrossRef]

171. Rajendran, S.; Harper, A. A simulation-based approach to provide insights on Hyperloop network operations. Transp. Res. Interdiscip. Perspect. 2020, 4. [CrossRef]

172. Cho, A. Hyperloop hope in Kansas City. ENR 2019, 282. Available online: https://www.enr.com/articles/47101-hyperloophope-in-kansas-city (accessed on 20 June 2021).

173. Pfoser, S.; Berger, T.; Hauger, G.; Berkowitsch, C.; Schodl, R.; Eitler, S.; Markvica, K.; Hu, B.; Zajicek, J.; Prandtstetter, M. Integrating High-Performance Transport Modes into Synchromodal Transport Networks. In Dynamics in Logistics; LDIC 2018; Lecture Notes in Logistics; Freitag, M., Kotzab, H., Pannek, J., Eds.; Springer: Cham, Switzerland, 2018. [CrossRef]

174. Voltes-Dorta, A.; Becker, E. The potential short-term impact of a Hyperloop service between San Francisco and Los Angeles on airport competition in California. Transp. Policy 2018, 71, 45-56. [CrossRef]

175. Markvica, K.; Hu, B.; Prandtstetter, M.; Ritzinger, U.; Zajicek, J.; Berkowitsch, C.; Hauger, G.; Pfoser, S.; Berger, T.; Eitler, S.; et al. On the development of a sustainable and fit-for-the-future transportation network. Infrastructures 2018, 3, 23. [CrossRef]

176. Schodl, R.; Eitler, S.; Ennser, B.; Breinbauer, A.; Hu, B.; Markvica, K.; Prandtstetter, M.; Zajicek, J.; Berger, T.; Pfoser, S.; et al. Innovative Means of Cargo Transport: A Scalable Method for Estimating Regional Impacts. Transp. Res. Procedia 2018, 30, 342-349. [CrossRef]

177. Werner, M.; Eissing, K.; Langton, S. Shared value potential of transporting cargo via hyperloop. Front. Built Environ. $2016,2$. [CrossRef] 